Note

\title{
Inhibitory Effects on Microbial Growth Using the Derivatives of Benzyl Phenyl Sulfide
}

\author{
AKIHIKO HATANO ${ }^{1 *}$, MUNEHIRO OKADA ${ }^{1}$, KEI SHIMAZAKI', \\ SANAE UEHARA ${ }^{1}$, YUTA ISHIKAWA', ARATA MATSUMOTO', \\ YUDAI FUJITA', AND MAKOTO NISHIMURA ${ }^{2}$ \\ 'Department of Chemistry, Shibaura Institute of Technology, \\ 307 Fukasaku, Minuma-ku, Saitama 337-8570, Japan \\ ${ }^{2} R$ \& D Center, Permachem Asia, Ltd. 14-29, \\ Torihama, Kanazawa-ku, Yokohama, Kanagawa 236-0002, Japan \\ Received 6 December, 2010/Accepted 12 February, 2011
}

\begin{abstract}
We investigated the antimicrobial activities of twelve derivatives of benzyl phenyl sulfide by using Minimum Inhibitory Concentration (MIC) and Minimum Bactericidal Concentration (MBC) values against 10 microbial strains. These derivatives of benzyl phenyl sulfides were synthesized by means of the nucleophilic coupling reaction at our laboratory. MIC testing revealed that all synthetic derivatives of benzyl and 4-methoxybenzyl phenyl sulfides had no effect against the tested microbial strains. However, the compounds of 4-nitrobenzyl phenyl sulfide showed antimicrobial activity against many of the tested strains. Above all, 4nitrobenzyl 4-chlorophenyl sulfide 11 exhibited the strongest and widest ranging inhibitory effects among the twelve synthetic compounds. We researched the antimicrobial activities of the coupling materials of sulfide. As a result, it was considered important for the expression of antimicrobial activities that the sulfide had a 4-nitrobenzyl group and 4-chlorophenyl group in the same molecule as in the case of benzyl phenyl sulfide.
\end{abstract}

Key words : Benzyl phenyl sulfide/Halogen group/Chemical structure/MIC/MBC.

Sulfide is an organic compound with a thioether bonding in its chemical structure. The derivatives of sulfide have special smells, and are found in plants such as garlic or onion. Medical supplies and antibacterial agents frequently contain the thioether bond in part of their molecular structure (Hsiao-C et al., 2010; Wu et al., 2004; Rattanachaikunsopon et al., 2008). For example, allyl sulfide, an important organosulfur component of garlic oil, has been reported to suppress the growth of multiple cancer cells in culture and in vivo models (Anna et al., 2008). We have hitherto researched the syntheses and function of unnatural nucleosides and nucleoside analogues (Hatano at al., 2004; 2008), and then reported their antibacterial and bactericidal activities (Hatano et al.,

*Corresponding author. Tel :+81-48-687-5035, Fax : +8148-687-5013, E-mail:a-hatano (a) sic. shibaura-it.ac.jp
2009). The benzyl sulfides were synthesized to investigate the unnatural nucleoside forming base pair reversibly and covalently using both a reducing agent and oxidizing agent. Derivatives of benzyl sulfide Bn$S-R$ (R: substituted group) were easily oxidized to produce the sulfoxide $\mathrm{Bn}-\mathrm{S}(=\mathrm{O})-\mathrm{R}$ form (Noguchi et al., 2008; Kirihara et al., 2009). Therefore, this chemical structure and oxidized property of benzyl sulfide could perform inhibitory and controlling actions on microbial strains in industrial setting and hospitals.

In this study, we tested the antimicrobial activities of twelve benzyl phenyl sulfide derivatives R-Bn-SPh-X (R: functional group, $X$ : halogen atom or hydrogen atom, Table 1) against 10 kinds of microbes. These compounds were classified into three groups with respect to their chemical structures. Group 1 consisted of sulfides possessing the benzyl group and substituted phenyl group whose substituents 
TABLE 1. Chemical structure and substituted groups and functional groups of tested benzyl phenyl sulfides.

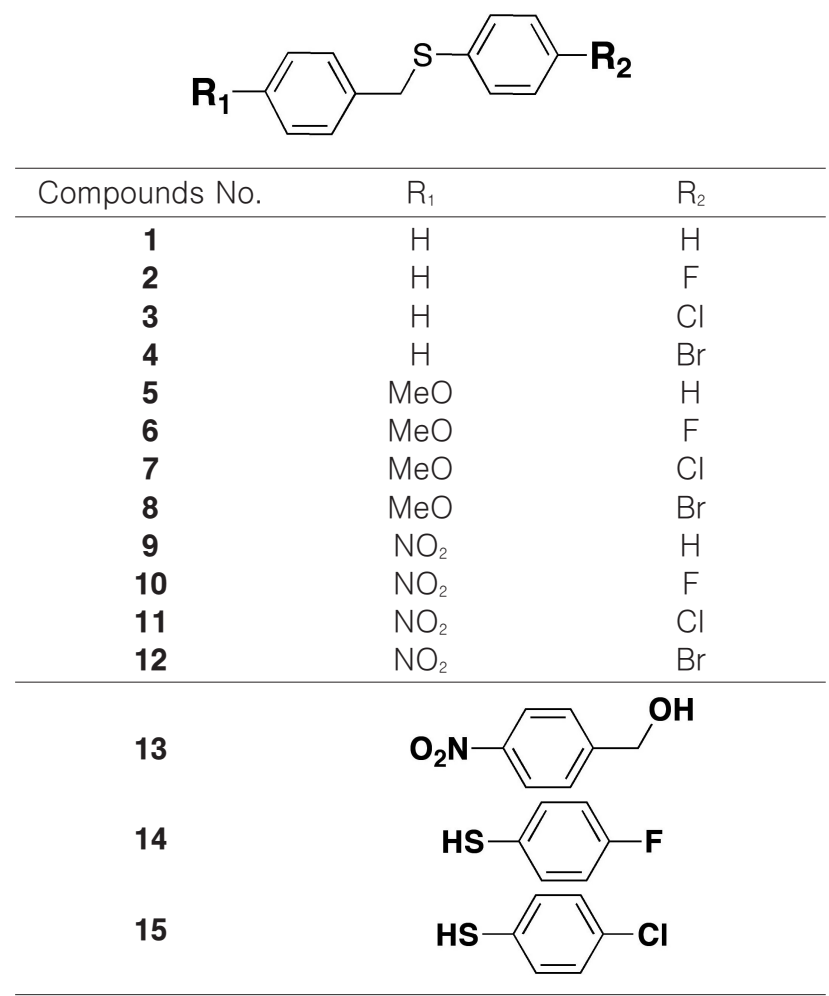

were a hydrogen, fluorine, chlorine, or bromine atom. The sulfides of group 2 had a 4-methoxybenzyl group and a hydrogenated or halogenated phenyl group. In group 3, there were sulfide derivatives with the 4nitrobenzyl group and phenyl group with a hydrogen or halogen atom at para position. These sulfides were different in a small functional group bound on the phenyl ring which was connected to the sulfur atom. These small functional groups influenced the electron density on the sulfur atom and phenyl ring because of their properties for electron-withdrawing and electronreleasing. We expected these properties would contribute to the antimicrobial activities. It is important to understand the relationship between antimicrobial activities and the structure and properties of sulfides that bound a variety of functional groups.

All tested compounds shown in Table 1 were synthesized in our laboratory based on previously reported methods (compound $\mathbf{1}$ (Alnajjar et al, 1992), 2-4 (Barry et al, 2009), 5 (Lai et al, 2002), 6 (Brookes et al, 1958), 7 (Kannan et al, 1999), 8 (Wang et al, 2003), 9 (Russell et al, 1979), 11 (Bandgar et al, 2002), 12 (Naso et al, 2009)). Purification of the synthesized compounds was carried out by recrystallization and column chromatography. Characterizations of these compounds were performed by TLC, ${ }^{1} \mathrm{H},{ }^{13} \mathrm{C}$, COSY NMR and elemental analysis. 4-Halogenated phenylthiols were coupled with 4-substituted benzylchloride, and then produced the desired 4-substituted benzyl 4-halogenated phenyl sulfide. The behavior of 4-fluorophenylthiol differed from that of other halogenated phenylthiols. The nucleophilicity of phenylthiol that substituted a hydrogen atom at the para position of the phenyl ring to a fluorine group, such as in the case of 4fluorophenylthiol, was very low, and this thiol did not react with 4-nitrobenzylchloride using as an electrophilic reagent under the condition of diisopropylethylamine in dichloromethane at room temperature. We tried this reaction with sodium hydride as a strong base in DMF to give the desired sulfide $\mathbf{1 0}$ at $86 \%$ yield. The general synthetic methods of derivatives (for example, for sulfide 7 ) and the new compound $\mathbf{1 0}$ of benzyl phenyl sulfide were as follows.

4-Methoxybenzyl 4-chlorophenyl sulfide (7), general procedure for the preparation of derivatives of benzyl phenyl sulfide. To a solution of 4chlorophenylthiol $(0.20 \mathrm{~g}, 1.4 \mathrm{mmol})$ in dry $\mathrm{CH}_{2} \mathrm{Cl}_{2}$ at $4{ }^{\circ} \mathrm{C}$ were added dropwise diisopropylethylamine (403 mg, $537 \mu \mathrm{L}, \quad 3.1 \mathrm{mmol}$ ), and 4methoxybenzylchloride (293 mg, $255 \mu \mathrm{L}, 1.9 \mathrm{mmol}$ ) over $5 \mathrm{~min}$. The mixture was stirred at room temperature for $30 \mathrm{~min}$. The resulting mixture was extracted with $\mathrm{CH}_{2} \mathrm{Cl}_{2}$ and the $\mathrm{CH}_{2} \mathrm{Cl}_{2}$ solution washed with water three times. The organic solvent was dried over $\mathrm{MgSO}_{4}$, and was evaporated in vacuo. The product was then recrystallized from 2-propanol to yield colorless needles of compound 7 (73\%, $0.27 \mathrm{~g}) .{ }^{1} \mathrm{H}-\mathrm{NMR}$ $\left(400 \mathrm{MHz}, \mathrm{CDCl}_{3}\right) \delta: 7.21(4 \mathrm{H}, \mathrm{s}), 7.18(2 \mathrm{H}, \mathrm{d}, J=$ $8.8 \mathrm{~Hz}), 6.82(2 \mathrm{H}, \mathrm{d}, J=8.8 \mathrm{~Hz}), 4.04(2 \mathrm{H}, \mathrm{s}), 3.79$ $(3 \mathrm{H}, \mathrm{s}) .{ }^{13} \mathrm{C}-\mathrm{NMR}\left(100.6 \mathrm{MHz}, \mathrm{CDCl}_{3}\right) \delta: 38.7,55.2$, $113.9,128.9,129.0,130.0,131.3,132.3,134.8$, 158.8. Anal. Calcd for $\mathrm{C}_{14} \mathrm{H}_{13} \mathrm{ClOS}$ : C, 63.51; H, 4.95 . Found: C, 63.43; H, 4.94 .

4-Nitorobenzyl 4-fluorophenyl sulfide (10). To a suspension of $\mathrm{NaH}(0.58 \mathrm{~g}, 60 \%$ in mineral oil, 17 $\mathrm{mmol})$ in dry DMF at $4{ }^{\circ} \mathrm{C}, 4$-fluorophenylthiol $(2.0 \mathrm{~g}$, $16 \mathrm{mmol}$ ) was added dropwise over $5 \mathrm{~min}$. The mixture was stirred for $20 \mathrm{~min}$. 4-Nitrobenzylchloride (3.0 $\mathrm{g}, 18 \mathrm{mmol}$ ) was then added dropwise to this mixture over 10 min at $4{ }^{\circ} \mathrm{C}$. The reaction mixture was allowed to warm to room temperature and was then stirred for $0.5 \mathrm{~h}$. The resulting mixture was extracted with ethyl acetate, and the ethyl acetate solution was washed with water three times. The organic solvent was dried over $\mathrm{Na}_{2} \mathrm{SO}_{4}$ and was evaporated in vacuo. The crude residue was purified by column chromatography on silica gel, eluted with hexane-toluene (15:1), and the product was then recrystallized from 2-propanol to yield colorless needles of compound $\mathbf{1 0}$ (86\%, 3.6 
g). ${ }^{1} \mathrm{H}-\mathrm{NMR}\left(400 \mathrm{MHz}, \mathrm{CDCl}_{3}\right) \delta: 8.12(2 \mathrm{H}, \mathrm{d}, J=$ $8.4 \mathrm{~Hz}), 7.31(2 \mathrm{H}, \mathrm{d}, J=8.8 \mathrm{~Hz}),, 7.26(2 \mathrm{H}, \mathrm{dd}, J=$ 4.4, $5.2 \mathrm{~Hz}), 6.96(2 \mathrm{H}, \mathrm{t}, J=8.0 \mathrm{~Hz}), 4.06(2 \mathrm{H}, \mathrm{s})$. ${ }^{13} \mathrm{C}-\mathrm{NMR}\left(100.6 \mathrm{MHz}, \mathrm{CDCl}_{3}\right) \quad \delta: 40.2,116.2,116.4$, 123.7, 129.1, 129.6, 134.4, 134.5, 145.5. Anal. Calcd for $\mathrm{C}_{13} \mathrm{H}_{10} \mathrm{FNO}_{2} \mathrm{~S}$ : C, 59.30; H, 3.83; N, 5.32. Found: C, 59.28; H, 3.89; N, 5.31.

All compounds were tested for antibacterial activities against Bacillus subtilis IFO-3134 (B.a.), Escherichia coli IFO-3806 (E.c.), Klebsiella pneumoniae IFO-3319 (K.p.), Pseudomonas aeruginosa IFO-12689 (P.a.), Staphylococcus aureus IFO-12732 (S.a.). Antifungal activities against Aspergillus niger IFO-6341 (A.n.), Penicillium citrinum IFO-6352 (P.C.), Debaryomyces hansenii var. hasenii IFO-1084 (D.h.), Geotrichum candidum IFO-4598 (G.c.), and Gliocladium virens IFO-6355 (G.v.) were also tested.

The minimum inhibitory concentration (MIC) tests of the compounds shown in Table 2 - 4 were performed by the agar dilution method of the Japan Society of Chemotherapy (Sakagami et al., 2007, Japan Society of Chemotherapy, 1993). First, all compounds were dissolved in $50 \%$ methyl diglycol in methanol solution at a maximum concentration of 20 $\mathrm{mg} / \mathrm{mL}(2 \% \mathrm{w} / \mathrm{w})$. Sulfide compounds were added into the agar medium at the desired concentrations $(1,5,10,50,100,200,500,1000 \mu \mathrm{g} / \mathrm{mL})$.

For the antibacterial assay, the bacteria were grown overnight at $37^{\circ} \mathrm{C}$ in broth medium (a mixture of $5.0 \mathrm{~g}$ meat extract, $10 \mathrm{~g}$ peptone and $5.0 \mathrm{~g} \mathrm{NaCl}$ dissolved in $1000 \mathrm{~mL}$ of sterilized water adjusted to $\mathrm{pH} 7.4$ by using $\mathrm{NaOH}$ solution). After the bacterial suspensions were mixed, $100 \mu \mathrm{L}$ of each suspension was added into $10 \mathrm{~mL}$ of sterile distilled water.
We applied $50 \mu \mathrm{L}$ of a bacterial suspension ( $10^{6}$ $\mathrm{cfu} / \mathrm{mL}, B$. subtilis vegetative cells) by a micropipette and glass spreader to a broth agar plate (containing $1.5 \%$ agar). The plates of bacteria were incubated at $37^{\circ} \mathrm{C}$ for $48 \mathrm{~h}$ and we determined the minimum inhibitory concentration based on the absence of colonies.

The protocol for the antifungal assay was similar to that for the antibacterial assay. Sabouraud agar plates were used for yeast, which contained $40 \mathrm{~g}$ glucose, $10 \mathrm{~g}$ peptone and $18 \mathrm{~g}$ agar dissolved in 1000 $\mathrm{mL}$ of sterilized water and adjusted to $\mathrm{pH}$ 5.6. The yeast was grown at $28{ }^{\circ} \mathrm{C}$ for 2 to 7 days. After a loopful was transferred to $10 \mathrm{~mL}$ of Sabouraud medium, the yeast culture was pre-incubated at $28{ }^{\circ} \mathrm{C}$ for $24 \mathrm{~h}$. Spores were resuspended in sterilized distilled water to obtain $10^{6} \mathrm{cfu} / \mathrm{mL}$ of the test yeast. Fungi were pre-incubated by growth at $28{ }^{\circ} \mathrm{C}$ for 2 to 7 days on a Sabouraud slope agar plate. $10 \mathrm{~mL}$ of sterilized distilled water was added to the agar plate and the resulting suspension was then filtered through sterilized gauze. This suspension, containing approximately $10^{6}$ $\mathrm{cfu} / \mathrm{mL}$, was added to each plate for MIC.

Table 2 shows the MIC values of twelve kinds of derivatives of benzyl phenyl sulfide. MIC testing revealed that all derivatives of benzyl phenyl sulfide and 4-methoxybenzyl phenyl sulfide had no effect against any microbial strain. However, the compounds of 4nitrobenzyl phenyl sulfide showed antimicrobial activity against many of the tested strains. 4-Nitrobenzyl phenyl sulfide $\mathbf{9}$ showed moderate effect against $B$. subtilis, E. coli, D. hasenii and G. candidum, and exhibited an MIC value of $200 \mu \mathrm{g} / \mathrm{mL}$. This compound 9 had a weak effect against the other microbial strains $(500 \mu \mathrm{g} / \mathrm{mL})$. Compound $\mathbf{1 0}$ with a fluorine group at $p$-phenyl position had a limited effect against

TABLE 2. Antimicrobial activities ( $\mathrm{MIC}, \mu \mathrm{g} / \mathrm{mL}$ ) of benzylphenylsulfide derivatives against 10 microbial strains.

\begin{tabular}{|c|c|c|c|c|c|c|c|c|c|c|c|c|}
\hline \multirow[b]{2}{*}{ Compounds No. } & & \multirow[b]{2}{*}{$\mathrm{R}_{2}$} & \multicolumn{10}{|c|}{$\mathrm{MIC}(\mu \mathrm{g} / \mathrm{mL})$} \\
\hline & & & B.s. & E.c. & K.p. & P.a. & S.a. & A.n. & P.c. & D.h. & G.c. & G.v. \\
\hline & 1 & $\mathrm{H}$ & $>1000$ & $>1000$ & $>1000$ & 1000 & $>1000$ & $>1000$ & $>1000$ & 1000 & $>1000$ & $>1000$ \\
\hline & 2 & $\mathrm{~F}$ & $>1000$ & 1000 & 1000 & 1000 & $>1000$ & $>1000$ & $>1000$ & 1000 & 1000 & 1000 \\
\hline & 3 & $\mathrm{Cl}$ & $>1000$ & $>1000$ & $>1000$ & 1000 & $>1000$ & $>1000$ & $>1000$ & 1000 & $>1000$ & $>1000$ \\
\hline & 4 & $\mathrm{Br}$ & $>1000$ & $>1000$ & $>1000$ & 1000 & $>1000$ & $>1000$ & $>1000$ & $>1000$ & 1000 & 1000 \\
\hline & 5 & $\mathrm{H}$ & $>1000$ & $>1000$ & $>1000$ & $>1000$ & $>1000$ & $>1000$ & $>1000$ & $>1000$ & 1000 & 1000 \\
\hline & 6 & $\mathrm{~F}$ & $>1000$ & $>1000$ & $>1000$ & 1000 & $>1000$ & $>1000$ & $>1000$ & $>1000$ & 1000 & 1000 \\
\hline & 7 & $\mathrm{Cl}$ & $>1000$ & $>1000$ & $>1000$ & 1000 & $>1000$ & $>1000$ & $>1000$ & $>1000$ & 1000 & 1000 \\
\hline & 8 & $\mathrm{Br}$ & $>1000$ & $>1000$ & $>1000$ & $>1000$ & $>1000$ & $>1000$ & $>1000$ & 1000 & 1000 & 1000 \\
\hline & 9 & $\mathrm{H}$ & 200 & 200 & 500 & 500 & 500 & 500 & 500 & 200 & 200 & 500 \\
\hline & 10 & $\mathrm{~F}$ & 200 & 500 & 1000 & 1000 & 500 & 1000 & 1000 & 1000 & 500 & 1000 \\
\hline & 11 & $\mathrm{Cl}$ & 200 & 200 & 200 & 1000 & 200 & 200 & 200 & 200 & 500 & 500 \\
\hline & 12 & $\mathrm{Br}$ & 1000 & 1000 & 1000 & 1000 & 1000 & 1000 & 1000 & 1000 & 1000 & 1000 \\
\hline
\end{tabular}

B.s.: Bacillus subtilis, E.c.: Escherichia coli, K.p.: Klebsiella pneumoniae, P.a.: Pseudomonas aeruginosa, S.a.: Staphylococcus aureus, A.n.: Aspergillus niger, P.c.: Penicillium citrinum, D.h.: Debaryomyces hansenii var. hasenii, G.c.: Geotrichum candidum, G.v.: Gliocladium virens. 
TABLE 3. Antimicrobial activities ( $\mathrm{MIC}, \mu \mathrm{g} / \mathrm{mL}$ ) of three coupling materials (4-halogenated phenylthiol and 4nitrobenzyl alcohol) and the mixture of each coupling materials against 10 microbial strains.

\begin{tabular}{crrrrrrrrrr}
\hline & \multicolumn{10}{c}{ MIC $(\mu \mathrm{g} / \mathrm{mL})$} \\
\cline { 2 - 10 } Compounds No. & \multicolumn{1}{c}{ B.s. } & \multicolumn{1}{c}{ E.c. } & K.p. & P.a. & S.a. & \multicolumn{1}{c}{ A.n. } & P.c. & \multicolumn{1}{c}{ D.h. } & G.c. & G.v. \\
\hline $\mathbf{1 3}$ & 1000 & 1000 & 1000 & 1000 & $>1000$ & 1000 & 1000 & 1000 & 1000 & 500 \\
$\mathbf{1 4}$ & $\mathbf{2 0 0}$ & $\mathbf{2 0 0}$ & 1000 & 1000 & 500 & 500 & 500 & 500 & 500 & 1000 \\
$\mathbf{1 5}$ & $\mathbf{5 0}$ & 1000 & 1000 & 1000 & $\mathbf{2 0 0}$ & 1000 & 1000 & 500 & 500 & 1000 \\
\hline $\mathbf{1 3 + 1 4}$ & $\mathbf{2 0 0}$ & $\mathbf{2 0 0}$ & 1000 & 500 & 500 & 500 & 500 & 500 & 500 & 500 \\
$\mathbf{1 3 + 1 5}$ & $\mathbf{5 0}$ & 1000 & 1000 & 1000 & $\mathbf{1 0 0}$ & 1000 & 1000 & 1000 & 500 & 1000 \\
\hline
\end{tabular}

B.s.: Bacillus subtilis, E.c.: Escherichia coli, K.p.: Klebsiella pneumoniae, P.a.: Pseudomonas aeruginosa, S.a.: Staphylococcus aureus, A.n.: Aspergillus niger, P.c.: Penicillium citrinum, D.h.: Debaryomyces hansenii var. hasenii, G.c.: Geotrichum candidum, G.v.: Gliocladium virens.

B. subtilis $(200 \mu \mathrm{g} / \mathrm{mL})$. 4-Nitrobenzyl 4chlorophenyl sulfide $\mathbf{1 1}$ showed the strongest and widest ranging effects among the twelve synthetic compounds, except for P. citrinum (MIC was 1000 $\mathrm{mg} / \mathrm{mL}$ ). However, we could not observe an effective MIC against any tested strain with compound 12, 4nitrobenzyl 4-bromophenyl sulfide.

We performed further investigation of antimicrobial activity of 4-nitrobenzyl 4-chlorophenyl sulfide $\mathbf{1 1}$. We researched the antimicrobial effect of coupling materials such as 4-nitrobenzylalcohol 13, 4fluorophenylthiol 14, and 4-chlorophenylthiol 15. As shown in Table 3, 4-nitrobenzylalcohol 13 had no effect against any microbial strain. The thiol compounds 14 and 15 inhibited the growth of a few microbes, B. subtilis (14: $200 \mu \mathrm{g} / \mathrm{mL}, 15: 50 \mu \mathrm{g} /$ $\mathrm{mL}$ ), E. coli (14: $200 \mu \mathrm{g} / \mathrm{mL}$ ), and S. aureus (15: $200 \mu \mathrm{g} / \mathrm{mL}$ ). Table 3 also indicated the effect on MIC of $1: 1$ ratio ( $w / w)$ of mixing reagents such as 4-nitrobenzyl alcohol $\mathbf{1 4}$ and halogenated thiols (14, 15). This result revealed that the effect of the stronger reagent could be seen in the MIC of a mixed

TABLE 4. Minimum bactericidal concentration (MBC, $\mu \mathrm{g} / \mathrm{mL}$ ) of benzylphenylsulfide 6 and coupling materials $\mathbf{1 4}, \mathbf{1 5}$. Only data for the three compounds that had inhibitory effects ( $\mathrm{MIC} \leq 500 \mu \mathrm{g} / \mathrm{mL}$ ) are shown.

\begin{tabular}{ccccr}
\hline & & \multicolumn{3}{c}{$\mathrm{MBC}(\mu \mathrm{g} / \mathrm{mL})$} \\
\cline { 3 - 5 } Compounds No. & Time/h & E.c. & P.a. & \multicolumn{1}{c}{ S.a. } \\
\hline $\mathbf{6}$ & 0.5 & 1000 & 500 & $>1000$ \\
& 1.0 & 1000 & 500 & 1000 \\
& 2.0 & 1000 & $\mathbf{2 0 0}$ & 500 \\
\hline \multirow{14}{*}{} & 0.5 & 500 & 500 & 1000 \\
& 1.0 & $\mathbf{2 0 0}$ & $\mathbf{2 0 0}$ & 1000 \\
& 2.0 & $\mathbf{2 0 0}$ & $\mathbf{2 0 0}$ & 1000 \\
\hline \multirow{14}{15}{} & 0.5 & $\mathbf{2 0 0}$ & $\mathbf{2 0 0}$ & 500 \\
& 1.0 & $\mathbf{2 0 0}$ & $\mathbf{1 0 0}$ & $\mathbf{2 0 0}$ \\
& 2.0 & $\mathbf{2 0 0}$ & $\mathbf{1 0 0}$ & $\mathbf{2 0 0}$ \\
\hline
\end{tabular}

E.c.: Escherichia coli, P.a.: Pseudomonas aeruginosa, S.a.: Staphylococcus aureus. sample. For example, it was shown that the MIC value of a mixture of $\mathbf{1 3}$ and $\mathbf{1 5}$ demonstrated the same MIC value as that of compound 15. From these results, it appeared that the antimicrobial effect of 4nitrobenzyl 4-chlorophenyl sulfide $\mathbf{1 1}$ was derived from its chemical structure of combining the 4nitrobenzyl group and 4-chlorophenyl group by sulfide bonding.

Minimum bactericidal concentration (MBC) tests of the sulfide derivatives shown in Table 4 were performed by the agar dilution method against three kinds of bacteria, E. coli, P. aeruginosa, and $S$. aureus. $10 \mathrm{~mL}$ of the desired final concentration of each antibacterial agent solution (10, 20, 50. 100, 200, 500, $1000 \mu \mathrm{g} / \mathrm{mL}$ in sterilized saline) was mixed with $50 \mu \mathrm{L}$ of a bacterial suspension $\left(10^{8}\right.$ $\mathrm{cfu} / \mathrm{mL}$ ), and left to stand for $0.5,1.0$, or $2.0 \mathrm{~h}$, respectively. After being mixed, $50 \mu \mathrm{L}$ of the solution was added to broth agar plates, which were then incubated at $28{ }^{\circ} \mathrm{C}$ for $48 \mathrm{~h}$. We determined the minimum inhibitory concentrations based on the presence or absence of colonies. MBC values did not change by addition of an inactivator. 4-Methoxybenzyl 4fluorophenyl sulfide $\mathbf{6}$ did not show effective MBCs against these bacteria during treatment for $1.0 \mathrm{~h}$ (500 $\mu \mathrm{g} / \mathrm{mL}$ ). However, it was demonstrated that 6 inhibited the growth of $P$. aeruginosa during mixing for 2.0 $\mathrm{h}$ with an $\mathrm{MBC}$ value of $200 \mu \mathrm{g} / \mathrm{mL}$. Compound $\mathbf{1 4}$ and $\mathbf{1 5}$ belong to the thiol derivatives which were coupling reactant based sulfides. 4-Fluorophenylthiol $\mathbf{1 4}$ had a low MBC $(200 \mu \mathrm{g} / \mathrm{mL})$ against $E$. coli and $P$. aeruginosa during mixing for $1.0 \mathrm{~h}$, however, had no MBC effect against $S$. aureus for 2.0 h. 4Chlorophenylthiol $\mathbf{1 5}$ had broad antibacterial activity against three kinds of bacteria. The MBC value of $\mathbf{1 5}$ was $100 \mu \mathrm{g} / \mathrm{mL}$ against $P$. aeruginosa for $1.0 \mathrm{~h}$. Also 15 showed weak activity $(200 \mu \mathrm{g} / \mathrm{mL})$ against $E$. coli during treatment for $0.5-2.0 \mathrm{~h}$ and $S$. aureus during treatment for $1.0-2.0 \mathrm{~h}$. It was found that the MBC of the other sulfide derivatives showed lower 
effectiveness against these bacteria.

In conclusion, we determined the antimicrobial activity of synthetic benzyl phenyl sulfide derivatives against 10 microbial strains. It was clear that the 4nitrobenzyl 4-harogenated phenyl sulfide had effective antimicrobial properties. In particular, 4nitrobenzyl 4-chlorophenyl sulfide $\mathbf{1 1}$ indicated wide ranging and strong effect (MIC of $200 \mu \mathrm{g} / \mathrm{mL}$ ) against seven microbial strains. The coupling reactants of sulfide were investigated for their MIC and $\mathrm{MBC}$ against ten microbial strains. As a result, it was considered important for the expression of antimicrobial activities that the sulfide had a nitro group and chloride group in the same molecule as in the case of benzyl phenyl sulfide.

\section{ACKNOWLEDGMENTS}

This work was partly supported by JGC-S Scholarship Foundation, Amano Institute of Technology, Hamamatsu Foundation for Science and Technology Promotion, Astellas Foundation for Research on Medicinal Resources, The Japan Securities Scholarship Foundation.

\section{REFERENCES}

Alnajjar, M. S., and Franz, J. A. (1992) A kinetic study of the migration of a phenyl group from sulfur to a carbon radical center: rearrangement of the $\alpha$-(phenylthio) benzyl radical, J. Am. Chem. Soc., 114, 1052-1058.

Anna A. P., and Shivendra V. S. (2008) Multitargeted prevention and therapy of cancer by diallyl trisulfide and related Allium vegetable-derived organosulfur compounds, Cancer Lett., 269, 305-314.

Bandgar, B. P., Pandit, S. S. and Nagargoje, S. P. (2002) Zinc-mediated simple and practical synthesis of sulfides, Sulf. Lett., 25, 247-249.

Barry, N., Brondel, N. Lawrence, S. E., and Maguire, A. R. (2009) Synthesis of aryl benzyl $\mathrm{NH}$-sulfoximines, Tetrahedron, 65, 10660-10670.

Brookes, R. F., Clark, N. G., Cranham, J. E., Greenwood, D., Marshall, J. R., and Stevenson, H. A. (1958) Toxicity of organic sulfides to the eggs and larvae of the two-spotted spider mite. IV. Benzyl phenyl sulfides substituted by halogens and other groups, J. Sci. Food Agric., 9, 111115.

Hatano, A., Harano, A., Takigawa, Y., Naramoto, Y., Toda, K., Nakagomi, Y., Yamada, H. (2008) Kinetic parameters and recognition of thymidine analogues substituted the functional group by thymidine phophorylase, Bioorg. Med. Chem., 16, 3866-3870.
Hatano, A., Makita, S., and Kirihara, M. (2004) Synthesis and characterization of a DNA analogue stabilized by mercapt C-nucleoside induced disulfide bonding, Bioorg. Med. Chem. Lett. 10, 2459-2462.

Hatano, A., Nishimura, M., and Souta, I. (2009) Impact of unnatural nucleosides on the control of microbial growth, Biocontrol Sci., 14, 55-60.

Hsiao-C. W., Jen-H. Y., Shu-C. H., and Lee-Y. S. (2010) Allyl sulfides inhibit cell growth of skin cancer cells through induction of DNA damage mediated $\mathrm{G}_{2} / \mathrm{M}$ arrest and apoptosis. J. Agric. Food Chem., 58, 7096-7103.

Japan Society of Chemotherapy (1993) Methods for the determination of minimum inhibitory concentration (MIC) by microdilution method (in Japanese). Chemotherapy (Tokyo), 41, 183-189.

Kannan, P., Banu, H. S., and Pitchumani, K. (1999) Syntheses of organic benzyl sulfides from thiols using a modified clay catalyst, Ind. Acad. Sci. Chem. Sci., 111, 555-561.

Kirihara, M., Yamamoto, J., Noguchi, T., and Hirai, Y. (2009) Selective synthesis of sulfoxides and sulfones by tantalum $(V)$ catalyzed oxidation of sulfides with $30 \%$ hydrogen peroxide. Tetrahedron Lett., 50, 1180-1183.

Lai, S., and Lee, D. G. (2002) Lewis acid assisted permanganate oxidations, Tetrahedron, 58, 9879-9887.

Naso, F., Capozzi, M. A. M., Bottoni, A., Calvaresi, M., Bertolasi, V., Capitelli, F., and Cardellicchio, C. (2009) A combined theoretical and experimental investigation on the enantioselective oxidation of aryl benzyl sulfides in the presence of a chiral titanium catalyst, Chem. Europ. J., 15, 13417-13426.

Noguchi, T., Hirai, Y., and Kirihara, M. (2008) Highly selective $30 \%$ hydrogen peroxide oxidation of sulfides to sulfoxides using micromixing, Chem. Commun., 26, 3040-3042.

Rattanachaikunsopon P., and Phumkhachorn, P. (2008) Diallyl sulfide content and antimicrobial activity against food-borne pathogenic bacteria of chives (Allium schoenopraum), Biosci. Biotechnol. Biochem., 72, $2987-$ 2991.

Russell, G. A., and Pecoraro, J. M. (1979) Pummerer reaction of para-substituted benzylic sulfoxides, J. Org. Chem. 44, 3990-3991.

Sakagami, Y., Sawabe, A., Komemushi, S., Ali, Z., Tanaka, T., Iliya, I., and linuma, M. (2007) Antibacterial activity of stilbene oligomers against vancomycin-resistant Enterococci (VRE) and methicillin-resistant Staphylococcus aureus (MRSA) and their synergism with antibiotics. Biocontrol Sci. 12, 7-14.

Wu, C. C., Chung, J. G., Tsai, S. J., Yang, J. H., and Sheen, L. Y. (2004) Differential effects of allyl sulfides from garlic essential oil on cell cycle regulation in human liver tumor cells. Food Chem. Toxicol., 42, 1937-1947.

Wang, C., Batsanov, A. S., Bryce, M. R., and Sage, I. (2003) An improved synthesis and structural characterisation of 2-(4-acetylthiophenylethynyl)-4-nitro5-phenylethynylaniline: The molecule showing high negative differential resistance (NDR), Synthesis, 13, 20892095. 